\title{
Pemurnian Minyak Genoak (Acorus calamus ) asal pulau Timor menggunakan Distilasi Pengurangan Tekanan
}

\author{
Rensy A. Henci, Reinner I. Lerrick, Theo Da Cunha
}

Fakultas Sains dan Teknik,Kupang, Indonesia, email: Henci20@yahoo.com

Artikel Ini Telah Diseminarkan Pada Seminar Nasional Saintek Unimor 2019

\section{Article Info}

\section{Article history:}

Received 23 Oktober 2019

Received in revised form 31 Mei 2020

Accepted 7 Juni 2020

\section{DOI:}

https://doi.org/10.32938/slk.v3i1.1039

\section{Keywords:}

Asaron,

Genok,

Distilasi pengurangan tekanan.

\section{Abstrak}

Telah dilakukan penelitian mengenai pemurnian minyak asaron hasil distilasi Stahl menggunakan distilasi pengurang tekanan. Pada penelitian ini dilakukan distilasi akar, batang dan daun genoak, kemudian minyak yang diperoleh dimurnikan dengan distilasi pengurangan tekanan. Rendemen hasil pemurnian distilasi pengurangan tekanan yang diperoleh yaitu 19,8\%. Hasil analisis FTIR, NMR dan GC-MS menunjukkan bahwa minyak genoak mengandung kemurnian senyawa asaron sebesar 90,49\%.

\section{Pendahuluan}

Di zaman ini resistensi antibiotik merupakan masalah serius yang menyebabkan menurunnya efektivitas pengobatan dan meningkatkan penularan infeksi bakter sehingga dapat meningkatkan resiko kematian yang secara lagsung berpengaruh pada menurunnya usia harapan hidup suatu negara. Data WHO (World Health Organization) menunjukkan angka kematian akibat resistensi sampai tahun 2013 terdapat sekitar 480 ribu kasus baru multidrug-resistent tuberculosis (MDR-TB), sehingga dengan cepatnya perkembangan dan penyebaran infeksi sehingga diperkirakan pada tahun 2050 kematian akibat bakteri resisten lebih besar dibanding kematian akibat kanker

Penelitian tentang isolasi antibiotik telah banyak dilakukan antara lain penemuan antibiotik Anthracimycin (Hensler dkk., 2014), Teixobactin (Ling dkk. 2015), Malacidin dari tanah (Lakemeyer dkk., 2018). Hasegawa dkk. (1975) telah melakukan isolasi senyawa aktif yang mengandung fragmen fumarat yaitu antibiotik C-9154 yang merupakan antibiotik berspektrum luas (Gambar 1). Antibiotik ini merupakan jenis antibiotik yang cukup potensial dan memiliki daya hambat pertumbuhan bakteri yang sebanding dengan beberapa jenis antibiotik yang lazim digunakan saat ini seperti penisilin, kemisitin, amfisilin dan eritromisin.

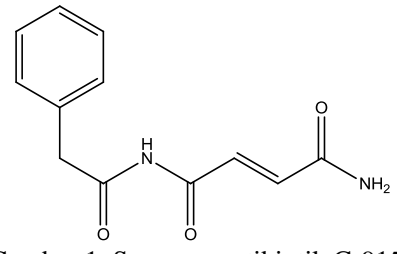

Gambar 1. Senyawa antibiotik C-9154

Jumina dan Subanar (2002) dengan melihat sruktur C-9154 membuat analog sintesis turunan antibiotik C-9154 dari etil salisil fumarat dan etil furfural fumarat (gambar 2 dan 3), etil salisil fumarat merupakan contoh turunan antibiotik C9154 yang mengandung gugus fenol, sedangkan etil furfural fumarat menjadi contoh turunan antibiotik C-9154 yang mengikat cincin furan.

Upaya sintesis analog antibiotik C-9154 (1) secara bertahap juga telah dilakukan oleh Safi'i (2010) yang telah mengoksidasi gugus alkena senyawa asaron(8) hasi destilasi genoak menggunakan Kalium Permanganat dengan katalis Tween 80 dan diperoleh senyawa 2,4,5-trimetoksi benzaldehida (9) dengan rendemen $27,04 \%$. Upaya optimalisasi oksidasi asaron juga dilakukan oleh Snae (2016) telah melakukan oksidasi Asaron (8) hasil destilasi Kaliraga asal Ende menggunakan oksidator $\mathrm{K}_{2} \mathrm{Cr}_{2} \mathrm{O}_{7}$ dan menghasilkan senyawa 2,4,5-trimetoksi benzaldehida (9) yang memiliki rendemen sebesar $50,17 \%$.

Oleh karena itu untuk mengoptimalisasi reaksi oksidasi yang telah dilakukan peneliti sebelumnya dalam menemukan senyawa antibiotik (1) yang lebih aktif dilakukan Distilasi Pengurangan Tekanan Minyak Genoak dan Optimalisasi Oksidasi Asaron metode Jones dengan pelarut Etil Asetat.

gel lidah buaya (Aloe vera) terhadap pertumbuhan bakteri S. aureus dan konsentrasi yang paling efektif dalam menghambat bakteri tersebut.

\section{Metode}

Penelitian ini dilakukan pada bulan Februari 2019 - Mei 2019 dengan lokas penelitian yaitu: Laboratorium Kimia Fakultas Sains dan Teknik Universitas Nusa Cendana Kupang. Analisis FT-IR dan NMR dilakukan di Laboratorium ITB Bandung, FMIPA Universitas Brawijaya Malang.

\section{A. Bahan}

Bahan-bahan yang digunakan dalam penelitian ini adalah: Tanaman Genoak, $\mathrm{CH}_{2} \mathrm{Cl}_{2}, \mathrm{H}_{2} \mathrm{O}, \mathrm{H}_{2} \mathrm{SO}_{4}$, Tween 80 dan $\mathrm{CH}_{3} \mathrm{COOH}, \mathrm{K}_{2} \mathrm{Cr}_{2} \mathrm{O}_{7}, \mathrm{Na}_{2} \mathrm{SO}_{4}$ anhidrat, dan Etil asetat.

B. Alat

Alat-alat yang digunakan dalam penelitian ini adalah: Peralatan gelas yang umumnya digunakan dalam laboratorium kimia organik, rotary evaporator (Buchi), timbangan digital, spektrofotometer-IR dan spektrometer NMR.

\section{Prosedur Penelitian}

1. Isolasi Minyak Atsiri dari Genoak

Tanaman genoak (Akar, batang dan daun) didistilasi secara terpisah. Sampel yang telah halus dimasukkan kedalam labu distilasi dan ditambahkan aquades secukupnya. Distilat yang diperoleh ditampung pada erlenmeyer, kemudian diekstraksi menggunakan diklorometana (3x $10 \mathrm{~mL})$. Ekstrak yang diperoleh dipisahkan antara fase organik dan fase air. Fase organik dikeringkan menggunakan $\mathrm{Na}_{2} \mathrm{SO}_{4}$ anhidrat kemudian disaring. Filtrat yang dihasilkan dievaporasi dan diperoleh minyak kemudian di KLT. Kandungan minyak yang diperoleh dinyatakan sebagai rendemen dalam satuan gram minyak/gram sampel.

2. Destilasi Pengurangan Tekanan Minyak Asaron

Dirangkai alat destilasi lalu ditimbang minyak asaron 5,39 gr dalam labu destilasi kemudian dimasukkan magnetik stirrer lalu dilakukan destilasi. Minyak murni asaron yang diperoleh kemudian dianalisis menggunakan FTIR dan NMR.

3. Oksidasi Asaron Menggunakan Pelarut Etil Asetat

Asaron sebanyak 0,5 $(2,40 \mathrm{mmol})$ gram hasil isolasi dimasukkan kedalam labu refluks yang telah dilengkapi dengan pengaduk magnet dan thermometer, kemudian ditambahkan $3 \mathrm{~mL} \mathrm{H}_{2} \mathrm{SO}_{4}$, Tween 80 dan $1 \mathrm{~mL}$ etil asetat pencampuran, selanjutnya campuran direfluks selama 1 jam sambil ditambahkan 0,7 (2,40 mmol) gram $\mathrm{K}_{2} \mathrm{Cr}_{2} \mathrm{O}_{7}$ secara perlahan dan diamati reaksi yang terjadi dengan kromatografi lapis tipis setiap 1 jam.

Campuran disaring kemudian filtrat yang diperoleh diekstraksi dengan $\mathrm{CH}_{2} \mathrm{Cl}_{2}(3 \times 10 \mathrm{~mL})$, dipisah antara fase organik dan fase air, fase organik dikeringkan menggunakan $\mathrm{Na}_{2} \mathrm{SO}_{4}$ anhidrat lalu disaring. Filtrat yang diperoleh dievaporasi, hasil evaporasi diKLT kemudian dimurnikan menggunakan kromatografi kolom dengan pelarut n-heksana : dietil eter. Fraksi yang diperoleh dievaporasi untuk menghilangkan pelarut, dan dihitung rendemennya.

\section{Hasil dan Pembahasan}

\section{A. Destilasi genoak}

Distilasi tanaman genoak dari akar, batang dan daun genoak (Acorus calamus) yang telah dilakukan menggunakan metode distilasi hidro (Stahl). Minyak asaron yang dihasilkan berwarna coklat, dari 50 gram sampel akar dan batang genoak diperoleh 1,83 gram minyak (rendemen sebesar 3,66\%) sedangkan dari 80 gram sampel daun diperoleh 1,26 gram (rendemen sebesar 2,1\%). Uji kemurnian minyak yang diperoleh selanjutnya dilakukan dengan KLT. Diperoleh nilai Rf sampel minyak dengan nilai Rf asaron pembanding yaitu 0,6 . Ini menunjukkan bahwa minyak hasil distilasi diduga adalah asaron. 


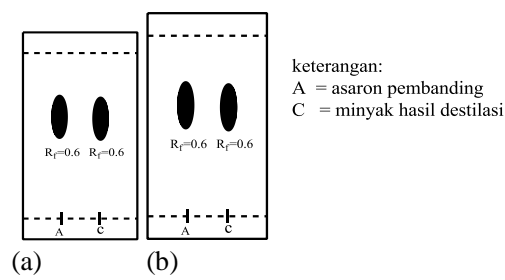

(a)

(b)

Gambar 2. Ilustrasi noda KLT hasil Destilasi sampel (a) Akar dan Batang, (b) Daun

B. Distilasi pengurangan tekanan minyak asaron

Minyak asaron yang telah diperoleh dari distilasi berwarna kecoklatan disebabkan ada senyawa-senyawa yang tidak diinginkan ikut terbawa selama distilasi. Oleh karena itu, pemurnian minyak akan dilakukan menggunakan metode pengurangan tekanan. Ke dalam rangkaian alat distilasi pengurangan tekanan dimasukkan minyak asaron yang berwarna coklat dalam labu distilat dan dilakukan distilasi hingga menghasilkan minyak asaron yang berwarna bening kekuningan. Minyak yang diperoleh kemudian diuji kemurniannya secara kualitatif (TLC) dengan perbandingan eluen n-heksan dan dietil eter (7:3) (Gambar 6). Adapun rendemen yang diperoleh dari pemurnian minyak asaron menggunakan distilasi pengurangan tekanan yaitu sebesar 19,8 \% dari penggunaan 5,39 gram sampel minyak asaron.

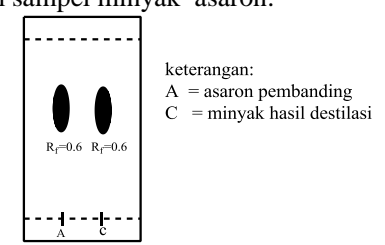

Gambar 3. Ilustrasi noda KLT hasil Distilasi pengurangan tekanan Produk minyak asaron pengurangan tekanan yang diperoleh kemudian dianalisis menggunakan instrumen FT-IR dan NMR. Adapun untuk hasil analisis FTIR dapat dilihat pada Gambar 4.

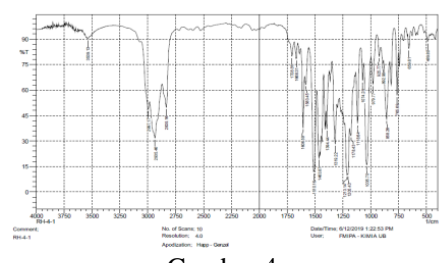

Gambar 4.

Tabel 1. Analisis serapan-serapan pada bilangan gelombang FTIR

\begin{tabular}{|c|l|c|}
\hline No & Gugus fungsional dan jenis vibrasi & $v\left(\mathrm{~cm}^{-1}\right)$ \\
\hline 1 & $\begin{array}{l}\text { Serapan pada bilangan gelombang menunjukkan } \\
\text { adanya rentangan } \equiv C_{\mathrm{sp} 3}-\mathrm{H}\end{array}$ & 2935,$19 ; 2835,16$ \\
\hline 2 & $\begin{array}{l}\text { Serapan pada bilangan gelombang menunjukkan } \\
\text { rentangan C=C aromatik }\end{array}$ & 1606,$59 ; 1510,16$ \\
\hline 3 & $\begin{array}{l}\text { Serapan pada bilangan gelombang menunjukkan } \\
\text { gugus metil dan metilen }\end{array}$ & 1394,$44 ; 1319,22$ \\
\hline 4 & Serapan menunjukkan adanya gugus eter & $1319,02-1035,70$ \\
\hline
\end{tabular}

Berdasarkan Gambar 4 hasil analisis FTIR dapat ditunjukkan adanya serapanserapan pada bilangan gelombang yang dapat dilihat dalam Tabel 5.Selanjutnya produk distilasi pengurangan tekanan minyak asaron dianalisis menggunakan instrumen ${ }^{1} \mathrm{H}-\mathrm{NMR}$ dan diperoleh spektra seperti terlihat pada Gambar 5.

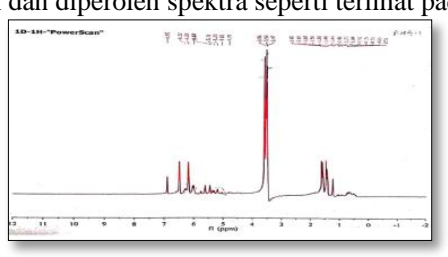

Gambar 5. Spektrum ${ }^{1}$ H-NMR hasil destilasi Pengurangan tekanan minyak asaron

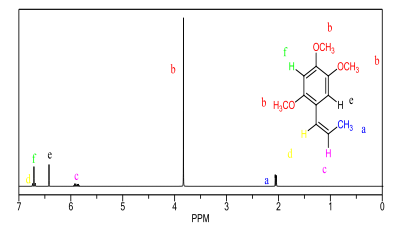

Gambar 6. Spektra ${ }^{1}$ H-NMR minyak asaron menggunakan permodelan ChemDraw

Dari data hasil analisis spektra ${ }^{1} \mathrm{H}-\mathrm{NMR}$ (Gambar 5), selanjutnya dilakukan perbandingan menggunakan permodelan Chem-Draw senyawa asaron dan diperoleh spektra ${ }^{1} \mathrm{H}-\mathrm{NMR}$ yang dapat dilihat pada Gambar 6.

Hasil identifikasi komponen kimia yang terkandung dalam Minyak Asaron sebelum distilasi pengurangan tekanan telah dilakukan oleh Snae (2016). Hasil analisis yang diperoleh dapat dilihat pada Gambar 7 .

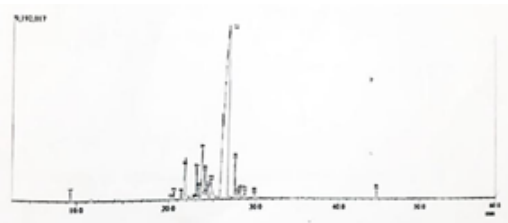

Gambar 7. Kromatogram minyak Asaron sebelum dimurnikan dengan distilasi pengurangan tekanan

Kromatogram minyak Asaron sebelum dilakukan pemurnian menggunakan distilasi pengurangan tekanan menunjukkan terdapat 19 puncak dengan waktu retensi yang berbeda dan mengandung beberapa jenis senyawa. Senyawa yang dominan adalah senyawa pada puncak 13 dengan waktu retensi 26,633 menit yang menunjukkan senyawa asaron dengan kemurnian $73,64 \%$ dengan indeks kemiripan (SI) sebesar $88 \%$.

Upaya pemurnian asaron dilakukan dengan distilasi Pengurangan Tekanan. Dari 5,39 gram minyak asaron hasil distilasi yang berwarna coklat diperoleh 1.07 gram minyak asaron yang berwarna kuning dengan rendemennya sebesar $19,8 \%$. Analisis kemurnian minyak asaron hasil distilasi Pengurangan Tekanan menggunakan GC-MS menunjukkan kemurnian minyak yang diperoleh sangat tinggi (Gambar 11) karena dari 9 puncak diperoleh puncak ke 7 yang paling tinggi dengan kemurnian $90 \%$. Hasil analisis yang diperoleh dapat dilihat pada Gambar 8.

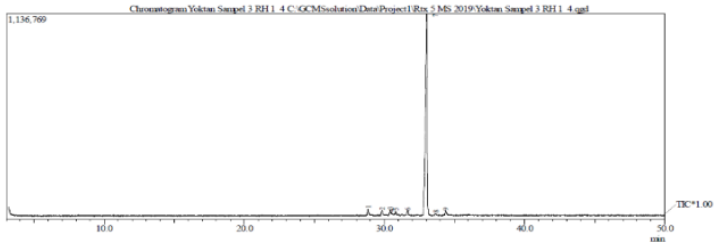

Gambar 8. Kromatogram hasil distilasi Pengurangan Tekanan Tabel 2. Waktu retensi dan presentase Kelimpahan Senyawa dalam Asaron

\begin{tabular}{|c|c|c|c|}
\hline No. Puncak & $\begin{array}{c}\text { Waktu retensi } \\
\text { (menit) }\end{array}$ & Luas area & Presentase (\%) \\
\hline 1 & 28,832 & 209819 & 1,92 \\
\hline 2 & 29,835 & 160972 & 1,48 \\
\hline 3 & 30,425 & 135432 & 1,24 \\
\hline 4 & 30,500 & 14127 & 0,13 \\
\hline 5 & 30,817 & 125899 & 1,15 \\
\hline 6 & 31,645 & 123348 & 1,13 \\
\hline 7 & 33,029 & 9864973 & 90,49 \\
\hline 8 & 33,677 & 77218 & 0,71 \\
\hline 9 & 34,372 & 190456 & 1,75 \\
\hline
\end{tabular}

Dari Tabel 2 terlihat bahwa minyak asaron yang telah dianalisis mengandung beberapa jenis senyawa, namun senyawa yang paling dominan adalah senyawa puncak 7 dengan waktu retensi 33,029 menit. Hasil spektogram massa puncak 7 dapat dilihat pada gambar 8 .

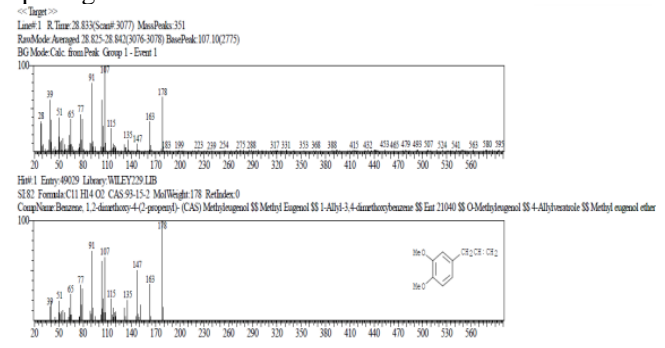

Gambar 9. Spektrogram massa puncak 7 dan massa puncak referensi Gambar 9 menunjukkan bahwa puncak 7 dengan waktu retensi 33,029 menit memiliki puncak dasar $\mathrm{m} / \mathrm{z}$ sebesar 178 . Berdasarkan perbandingan dengan spekrogram massa referensi pada gambar diatas, maka dapat disimpulkan bahwa senyawa tersebut adalah senyawa asaron dengan kemurnian 90,49\% dengan indeks kemiripan (SI) sebesar 82\%. Berdasarkan hasil analisis FT-IR, NM dan GC-MS maka dapat disimpulkan bahwa minyak genoak mengandung senyawa asaron dengan kemurnian sebasar $90,49 \%$. Asaron ini yang akan dioksidasi menggunakan $\mathrm{K}_{2} \mathrm{Cr}_{2} \mathrm{O}_{7}$.

\section{Simpulan}

Dari penelitian yang telah dilaksanakan maka kesimpulan yang diperoleh yaitu Proses pemurnian minyak asaron yang berwarna coklat dapat dimurnikan dengan destilasi tekanan uap sehingga diperoleh rendemen sebesar 19,8\% dengan kemurnian sebesar 90,49\%.

\section{Pustaka}

Agusta, A. 2000. Minyak Atsiri Tumbuhan Tropika Indonesia.Penerbit ITB, Bandung. 
Amstrong, Daniel., Kimber dan Chen. 2018. Evaluation of the Macrocyclic Antibiotic Vancomycin as a Chiral Selector for Capillary Electrophoresis.University of Missouri-Rolla, Missaouri.

Hasegawa, Toru., Mitsuko., dan Konomi. 1975. A new Antibiotic C-9154. Takeda Chemical Industries, Juso, Yodagawa-ku, Osaka, Japan.

Hensler, Kyoung., Wdee.,dan Lisa. 2014. Anthracimycin Activity Against Contemporary Methicillin-Resistant Staphylococcus aereus. J Antibiot, Tokyo.

Jumina, Siswanta., dan D., Zulkarnain. A. K. 2001. Sintesis dan uji aktivitas biologis Turunan antibiotik C-9154 dari Vanilin. Majalah Farmasi. Hal $12,2,85-91$.

King, Anthony. 2016. Resistance Set to Kill 300m by 2050, Chemistry World Magazine On July, News and analysis.

Kindsher, Kelly. 1992. Medicinal wild plants of the prairie: An ethnobotanical guide. University Press of Kansas, Lawrence.

Lakemeyer., Zhao., Mandl. 2018. Thinking outside the Box- Antibacterials to Tackle the Resistance Crisis. Antibacterial Drug. Angewadte chemie. Weinheim. Hal 2-39.

Ling, Schneider., Peoples AJ. 2015. A new an Antibiotik Kills Pathogens without Decetable Resistance, Novobiotik Pharmaceuticals, Cambrigde, USA.

Lerrick, R.I. 2010. Buku Penentuan Struktur Senyawa Organik, Universitas Nusa Cendana, Kupang.

Safi'i, A. 2010. Oksidasi Gugus Alkena Senyawa Asaron Hasil Destilasi Genoak (Acorus calamus) Menggunakan Kalium Permanganat Dan Katalis Tween 80, Skripsi, Undana, Kupang.

Snae, S.S,. 2016. Oksidasi Asaron Hasil Destilasi Kaliraga (Acorus calamus) Asal Ende dengan menggunakan Oksidator $\mathrm{K}_{2} \mathrm{Cr}_{2} \mathrm{O}_{7}$, skripsi, Undana, Kupang. 